\title{
Canopy composition and site are indicative of mineral soil conditions in Patagonian mixed Nothofagus forests
}

\author{
Mónica Toro-Manríquez ${ }^{1,2}$ (1) $\cdot$ Rosina Soler ${ }^{1,2} \cdot$ María Vanessa Lencinas $^{1,2} \cdot$ Álvaro Promis $^{3}$
}

Received: 10 June 2018 / Accepted: 24 September 2019/Published online: 13 December 2019

(C) INRA and Springer-Verlag France SAS, part of Springer Nature 2019

\begin{abstract}
- Key message Canopy composition in mixed Patagonian Nothofagus forests has an impact on soil properties like cationic exchange capacity and pH, while most soil variables changed with site $[\mathrm{P}$, cation exchange capacity (CEC), soil moisture (SM), resistance to penetration (R)]. Site conditions and canopy composition need be considered together to better understand the distribution of Nothofagus species.

- Context Forests can influence soil development, changing main soil properties by several mechanisms, but this has never been investigated in mixed Nothofagus forests. Such influences can be strongly variable depending on local site conditions, and the interactions between both factors need to be clearly established.

- Aims To reveal the effect on physical and chemical mineral soil properties in mixed Nothofagus forests of canopy composition and their interactions with site conditions.

- Methods Two sites and three mixed forest types, with different proportion of deciduous-evergreen, were selected in coastal and mountain sites. We evaluated forest structure, litterfall and physico-chemical properties of mineral soil $(N=60)$, and analyzed these factors with general linear models and multivariate statistics [multi-response permutation procedure (MRPP), principal component analyses (PCA)]. - Results Basal area and litterfall were significantly influenced by forest type $\times$ sites. $\mathrm{CEC}$ and $\mathrm{pH}$ value varied among forests types and sites, but sites also influenced other variables (P, SM, R). Multivariate analyses reveals a much stronger effect of site conditions than that of species mixture.

- Conclusion Forest soil studies must consider environmental factors on different spatial scale and canopy species composition to better understand their influence on soil dynamics in mixed Nothofagus forests.
\end{abstract}

Keywords Deciduous broadleaf forest $\cdot$ Evergreen broadleaf forest $\cdot$ Litter input $\cdot$ Mineral soil properties $\cdot$ Nothofagus $\cdot$ Site conditions

Handling Editor: Andreas Bolte

Contributions of co-authors Mónica Toro Manríquez contributed to methodology, field sampling, data analyses, writing the original draft, reviewing and editing

Rosina Soler contributed to methodology, field sampling, reviewing and editing the manuscript

María Vanessa Lencinas contributed to methodology, field sampling, data analysis, reviewing and editing the manuscript

Álvaro Promis contributed with data analysis, reviewing and editing the manuscript

Mónica Toro-Manríquez

monicatm@cadic-conicet.gob.ar

Rosina Soler

monicatm@cadic-conicet.gob.ar

1 National Council of Scientific and Technical Research (CONICET), Godoy Cruz 2290 (1425), Buenos Aires, Argentina
2 Agroforestry Resources Laboratory, Austral Centre for Scientific Research (CADIC-CONICET) Houssay 200 (9410), Ushuaia, Tierra del Fuego, Argentina

3 Department of Silviculture and Nature Conservation, University of Chile, Av. Santa Rosa 11315 (9206), La Pintana, Santiago, Chile 


\section{Introduction}

Physical and chemical soil properties are key factors that can contribute to forest species distribution at a regional level (Quesada et al. 2009; Li et al. 2013), as well as latitude and altitude, which strongly determine climate (Augusto et al. 2002). Likewise, species composition can also influence soil development, changing edaphic properties (Boyle 2005; Li et al. 2013). Trees can differ in their effects on soil by many mechanisms, including rates of chemical weathering of parental material through changes in $\mathrm{pH}$ and composition of the complex organic acids of soil solutions (Augusto et al. 2002). However, the effect of trees on soil mineral weathering occurs almost exclusively in topsoil (Augusto et al. 2000) or near the roots (Courchesne and Gobran 1997). In contrast, other effects of trees on soils may have developed with only a modest, or no, connection to plant fitness or its proximity, such as interception rates of atmospheric pollutants or rates of soil podzolization (Binkley and Giardina 1998). Moreover, some chemical properties of forest soils can be influenced by small-scale factors, such as litter input, stand species composition, and microclimate variables, while other variables with long-term effects (e.g., permanent vegetation over a long period) or drastic alterations (e.g., fires, intensive harvesting) mainly affect soil structure and its physical properties (Osman 2013). For example, the litter input contribution varies with canopy tree species composition (e.g., broadleaf or needle leaf, deciduous or evergreen, pure or mixed tree species), because they have different decomposition rates and nutrient contents (Augusto et al. 2002; Vesterdal et al. 2008). Canopy composition can also influence soil structure (Augusto et al. 2002), being significant in the upper layers of soils near the roots (Binkley and Valentine 1991) and correlated with stand density (Rothe and Binkley 2001). Similarly, there can be substantial differences in the rates of mineralization under different species (Binkley and Giardina 1998), and mixing species can result in increased mineralization rates compared with monocultures of species with slower rates of mineralization. In this sense, both physical and chemical properties interact with each other, determining soil fertility and forest productivity, with soil fertility also being influenced by the interaction between trees and other components of the ecosystem, not only by the tree-soil interaction (Binkley and Giardina 1998).

Natural temperate forests have a variable composition, ranging from pure broadleaf or needle leaf tree species, to mixtures of different deciduous or deciduous-evergreen tree species, and they occur in a wide range of soils, topographies and climates (Dreiss and Volin 2013). The northern hemisphere has a higher presence of needle leaf evergreen tree species (conifers), which influences soils, making them relatively more acidic and nutrient poor (Vankat 2002; StClair and Lynch 2005). Coniferous species tend to decline in abundance further south.
At lower latitudes, broadleaved deciduous species coexist with broadleaved evergreen species, forming unique mixed forests in the Southern hemisphere where evergreen and deciduous understorey communities meet and integrate (Mestre et al. 2017). In these austral ecosystems, the presence of deciduous species promotes deeper and more fertile soils than pure evergreen forests (Dreiss and Volin 2013). In Southern Patagonia (Argentina), two Nothofagus (Fagaceae) species compose pure and mixed forests: the deciduous Nothofagus pumilio and the evergreen $N$. betuloides (Frangi et al. 2005).

Soil characteristics in Nothofagus forests reflect the influence of the dominant pedogenic processes that differ between evergreen (waterlogging) and deciduous (podzolization) forests according to Frangi et al. (2005) and Romanya et al. (2005). Thus, soil properties may contribute to the local distribution (at stand level) of both Nothofagus species (Frangi et al. 2005). Similarly, Thiers and Gerding (2007) argued that, under homogeneous climatic conditions (i.e., short variation of annual temperature at latitudinal scale), topography and soil variables play a significant role in explaining the distribution ranges of Nothofagus species. These statements could explain, on a regional scale, the distribution of pure Nothofagus forests over a large topographic and geographic range (with greater variation of soil properties), where $N$. pumilio occurs at cooler and drier places, and $N$. betuloides at temperate and rainier ones (Frangi and Richter 1994; Thiers and Gerding 2007). However, N. pumilio and N. betuloides forests develop jointly at several locations of the Tierra del Fuego archipelago, forming mixed forests at sea level or near coastlines or large water bodies (e.g., Beagle Channel and lakes), where the extreme cold temperatures are buffered (Donoso and Donoso 2006). Besides this, mixed forests also develop in the middle slope of mountains surrounding wide valleys, where temperature inversion occurs (Frangi et al. 2005). In these forest types, deciduous trees are considered ameliorative species, as they increase the degradable nutrients available to evergreen stands (Frangi and Richter 1994; Brunel et al. 2017).

At coastal or mountain sites, forest soils originated over the same parental material, by a single pedogenic process, developing a unique topography and under more or less uniform soil conditions. Despite this, mixed deciduous-evergreen Nothofagus forests are usually heterogeneous ecosystems composed of patches that vary in their relative proportion of tree species. Consequently, the proportion of deciduousevergreen trees in the canopy could influence chemical and physical soil properties, and therefore the ecological processes that depend of them (e.g., seedling recruitment, growth and survival). Furthermore, differences in soil fertility, along with local climate conditions, determine forest structure development, tree density, age classes, diameter and height (Bahamonde et al. 2018). This study aimed to reveal the effects of canopy composition (different proportion of deciduous and evergreen species, as well as their interactions) at 
coast and mountain sites, on the physical and chemical properties of mineral soils in mixed Nothofagus forests. Regarding chemical properties, study of the complete set of macro and micronutrients is desirable, but we focused on soil nitrogen and phosphorus because these are considered the most limiting nutrients for Nothofagus forest development (Diehl et al. 2003; Romanya et al. 2005), as well as for net primary production in many temperate ecosystems (Bingham and Cotrufo 2016). Currently, the study of tree species composition influencing soil carbon and nitrogen concentrations has gained interest in the scientific community due to their role in greenhouse gas mitigation (Jandl et al. 2007) by carbon sequestration in soils (de Vries et al. 2006).

Cycling of limiting nutrients such as nitrogen and phosphorous from litter decomposition in deciduous $N$. pumilio forests occurs faster than in evergreen $N$. betuloides forests (Frangi et al. 2005). Evergreen canopies produce detritus of low nutrient concentration with lower decomposition rates (Frangi et al. 2005). Therefore, we assume that such differences can influence the content and storage of the main nutrients in the mineral soil layer, and we expect to detect contrasting values between canopies dominated by deciduous or evergreen species, due mainly to the differences in litter quality described above. Within the mixed canopy forest (similar proportion of deciduous-evergreen species), the content and storage of these nutrients are expected to be intermediate. In addition, phosphorous availability improves in soils with neutral $\mathrm{pH}$ compared with acidic or alkaline environments (Thiers et al. 2014). Thus, we also expect a significant effect of site conditions on soil properties from two contrasting geographical locations (coast and mountains), given the specifics of the process of soil formation (Romanya et al. 2005). We believe our findings represent a significant step towards better understanding of the influence of tree canopy composition on mineral soil characteristics and site-related factors at these latitudes.

\section{Material and methods}

\subsection{Study area and soil description}

This study was developed in old-growth Nothofagus forests ( $>250$ years) in the southwest part of Tierra del Fuego Island, Southern Patagonia, Argentina. The studied forests are undisturbed stands without harvesting signals for the last 50 years. We selected two sites (contrasting geographic locations) with two replicas each: (1) the coast close to the Beagle Channel, and (2) the mountain toward the inner island (Fig. 1). The coast sites were located within the Tierra del Fuego National

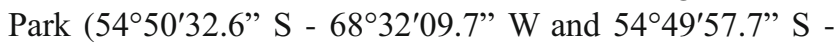
$68^{\circ} 26^{\prime} 39.4^{\prime \prime} \mathrm{W}$ ), at an altitude of 50-100 m.a.s.1.. The mountain sites were located at Garibaldi Pass (National Route $\mathrm{N}^{\circ} 3$ ) in the southernmost part of the Andes Mountain Range $\left(54^{\circ} 41^{\prime} 10.8^{\prime \prime} \mathrm{S}-67^{\circ} 48^{\prime} 58.9^{\prime \prime} \mathrm{W}\right.$ and $54^{\circ} 41^{\prime} 00.8^{\prime \prime} \mathrm{S}-67^{\circ} 48^{\prime}$
00.4 " W), where the elevation is $300-370$ m.a.s.l. Vegetation at both sites $(<400$ m.a.s.l) is dominated by Nothofagus forests (Moore et al. 1983), which have been classified as mixed forests at a regional scale (Collado 2001). However, it is possible to differentiate stands with greater predominance of one species in the canopy or totally mixed canopies. For this, we selected three forest types per replica, with different proportion of deciduous-evergreen canopy, using visual estimations in satellite images: (1) $>80 \%$ of canopy composed of the deciduous $N$. pumilio (hereafter Np); (2) $>80 \%$ of canopy composed by the evergreen $N$. betuloides (hereafter $\mathrm{Nb}$ ) and (3) canopy with similar proportion of deciduous $N$. pumilio and evergreen $N$. betuloides canopy cover (hereafter $\mathrm{M}$ ). We verified the forest types during the forest structure survey.

Climate in the study area is influenced by oceanic currents, the proximity of Antarctica, and insularity features that determine a uniform climate regime with a low range of annual temperature $\left(7-10^{\circ} \mathrm{C}\right)$ (Burgos 1985). In coastal sites, the average monthly temperature varies between 2.1 and $10.9{ }^{\circ} \mathrm{C}$, and accumulated rainfall is $710 \mathrm{~mm} \mathrm{year}^{-1}$, while, in the mountain sites, the average monthly temperature varies between -0.6 and $7.2^{\circ} \mathrm{C}$, and accumulated rainfall is $545 \mathrm{~mm}_{\text {year }}{ }^{-1}$ (Kreps et al. 2012). The parent materials of soils in the study area are metamorphic rocks, modulated by glacial processes (Frederiksen 1988). Both locations correspond to undulating lateral moraines due to the " $U$ " shape of the valleys, with low elevations and soft slopes at the coast, and high elevations and steep slopes in the mountains. There is a lack of recent volcanic material (post-plestocenic), and the effect of glacial and post-glacial phenomena (e.g., sediments and glacier deposits) on the pedogenesis of local soils is remarkable (Pisano 1977; Ibarra et al. 2007). In general, Nothofagus forest soils in Tierra del Fuego have been classified as podzols (Gerding and Thiers 2002) according to IUSS Working Group WRB (2015). Nothofagus forest soils are loamy texture, with massive granular structures, low usable water capacity and moderate-to-slow internal and external drainage. These soils in the study area are characterized by an organic uppermost layer up to $2 \mathrm{~cm}$ thick (O horizon), followed by a mineral layer, of less than $40 \mathrm{~cm}$ where most roots develop (mostly A horizon), with a variable proportion of stony material (Contreras et al. 1975). The first soils layers in Nothofagus forests ( $\mathrm{O}$ horizons at $<5 \mathrm{~cm}$ and A horizons $<30 \mathrm{~cm}$ ) account for most of the soil fertility (Peña-Rodríguez et al. 2013).

\subsection{Forest structure and litterfall estimation}

Forest structure was characterized by five randomly located plots at each forest type and replica $(N=3 \times 2 \times 2 \times 5=60)$ and using the angle count sampling method (Bitterlich 1984). A Criterion RD-1000 (Laser Technology, Centennial, CO) was used $(\mathrm{k}=$ basal area factor between 6 and 7) to determine the basal area $\left(\mathrm{BA}, \mathrm{m} \mathrm{ha}^{-1}\right)$ and tree density $\left(\mathrm{TD}\right.$, ind ha ${ }^{-1}$ at stand level. Additionally, dominant height (DH) was estimated using 


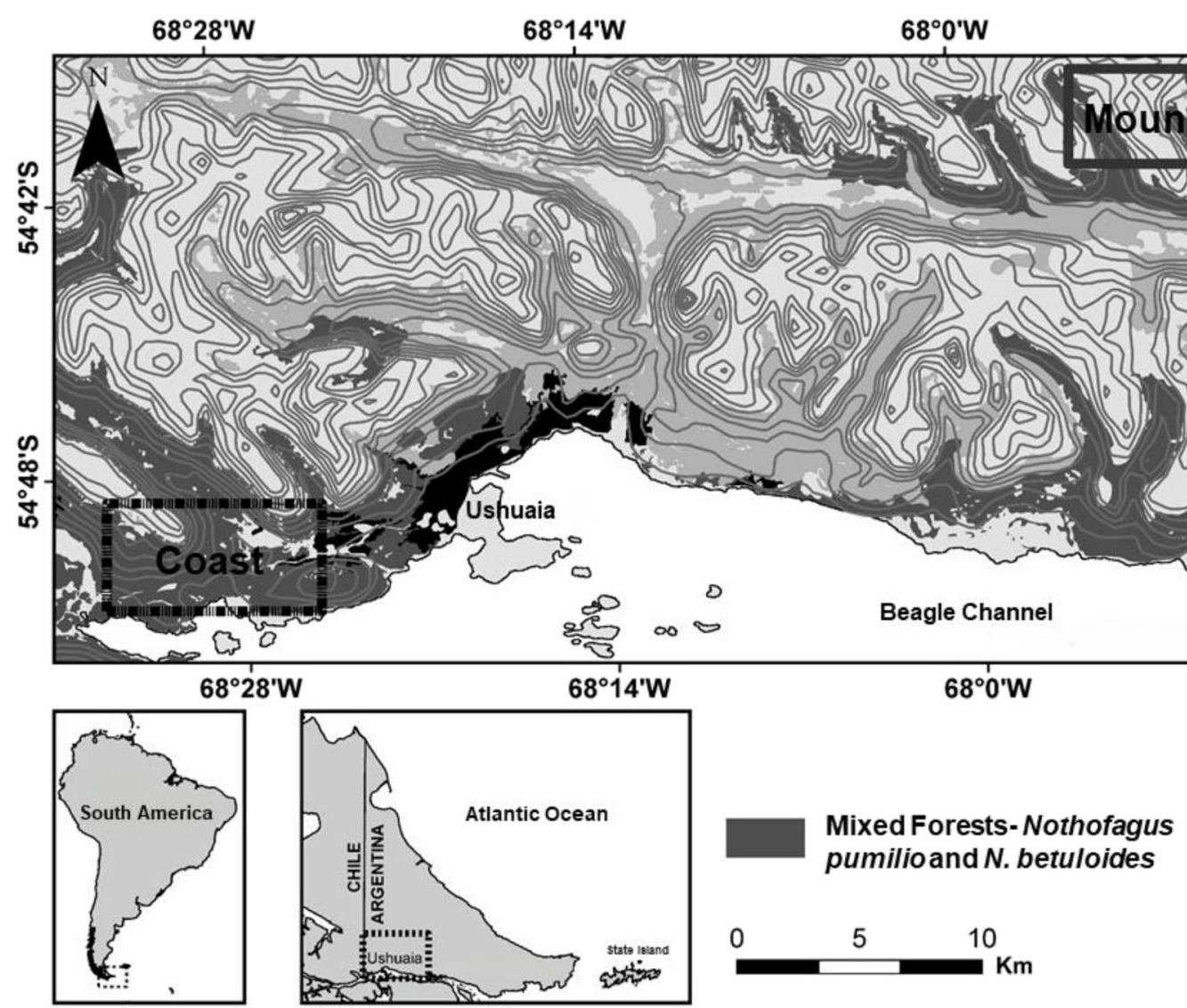

Fig. 1 Location of the study area in Tierra del Fuego Island, Argentina. Rectangles Sampling sites on the coast of the Beagle Channel and the Andes Mountains

a TruPulse 200 laser clinometer and distance rangefinder (Laser Technology) by averaging height of the three taller trees per plot. Also, species and diameter at breast height (DBH) was determined for each tree included in each plot. These data were collected between October and December 2012. On the other hand, litterfall was monitored monthly using 10 traps $(0.06 \mathrm{~m}$ and $30 \mathrm{~cm}$ deep) located randomly at each forest type and replica $(N=3 \times 2 \times 2 \times 1=120)$. The traps were perforated to allow rain and snow-water drainage. Fallen litter structures were separated manually, classified by tree species, and dried in an oven at $70^{\circ} \mathrm{C}$ to constant weight. The dry material was weighed with a precision of $\pm 0.0001 \mathrm{~g}$ to calculate annual biomass $\left(\mathrm{L}, \mathrm{t} \mathrm{ha}^{-1}\right.$ year $\left.^{-1}\right)$. These data were collected between October 2012 to May 2013 (see more details about forest structure in Toro Manríquez et al. 2016; Mestre et al. 2017).

\subsection{Mineral soil sampling}

Soil samples were dried in an oven at $70{ }^{\circ} \mathrm{C}$, ground in an analytical mill (type Cole-Parmer, Vernon Hills, IL) and then sieved $(2 \mathrm{~mm})$. Samples were analyzed at the Laboratory of Soil Science (Department of Natural Resources, Faculty of Agricultural Sciences, National University of Cordoba) to determine: soil organic matter concentration (SOM, \%) and soil organic carbon concentration (SOC, \%) with LECO analyzer; total nitrogen concentration $(\mathrm{N}, \%)$ using the Kjeldahl method; phosphorus concentration $(\mathrm{P}, \mathrm{ppm})$ by the Bray and Kurtz method (Bray and Kurtz 1945); and cation exchange capacity (CEC, meq $100 \mathrm{~g}$ ) using ammonium acetate (Wenk and Bulakh 2004). The carbon/nitrogen ratio $(\mathrm{C} / \mathrm{N})$ was then calculated from the concentration of SOC and N, and carbon/ phosphorus ratio $(\mathrm{C} / \mathrm{P})$ was obtained from the concentration of SOC and P. Mineral soil texture (proportion of sand \%, silt \%, clay \%) was determined using the Bouyoucos method (Bouyoucos 1936). The soil $\mathrm{pH}$ was also determined at the Agroforestry Resources Laboratory (CADIC) using an Orion pH-meter. Simultaneously, five other soil samples per stand were taken at $5 \mathrm{~cm}$ deep to determine soil bulk density (SD, g $\mathrm{cm}^{-3}$ ) using cylinders of known volume $\left(84.7 \mathrm{~cm}^{3}\right)$ in undisturbed soil to extract samples. The gravel or stone component in the sampled horizon and depth is small or absent, so we did not use any coefficient to fit the assessed soil volume. Once in the laboratory, soil samples were dried in an oven at $70{ }^{\circ} \mathrm{C}$, before weighing on a precision balance $( \pm 0.0001 \mathrm{~g})$. Moreover, during January 2014, we measured soil resistance to penetration (which is related to soil compaction) and soil 
moisture, both with five measurements along five transects ( $5 \mathrm{~m}$ length each, measurements at $1 \mathrm{~m}$ interval) per stand, and the values were averaged for each forest type and replica. The soil resistance to penetration (R), Newton $\mathrm{cm}^{-2}$ ) was determined using a manual penetrometer (Eijkelkamp Agrisearch Equipment, Giesbeek, The Netherlands) up to $30 \mathrm{~cm}$ deep, while the soil moisture (SM, \%) was determined with an MP406 moisture probe (ICT, Armidale, NSW, Australia) at $6 \mathrm{~cm}$ deep. We first removed the organic layer $(<2 \mathrm{~cm})$ to measure these two variables. Soil temperature (T, ${ }^{\circ} \mathrm{C}$ ) was recorded using 12 data loggers (model H8, HOBO, Onset, Bourne, MA) located $20 \mathrm{~cm}$ deep during a 1-year cycle (one data logger per stand). For SOC, SOM, N and P we also estimated storage per unit area in the mineral soil, using the equation: Storage $\left(\mathrm{Mg} \mathrm{ha}^{-1}\right)=$ concentration $(\%) \times$ soil density $\left(\mathrm{SD}, \mathrm{g} \mathrm{cm}^{-3}\right) \times$ soil depth $(5 \mathrm{~cm})$.

\subsection{Statistical analysis}

General linear models on a mixed model nested ANOVA design were used to test the effects of forest type, sites (both fixed factors) and replica (random factor), with forest type $\times$ replica nested in sites, over all the analyzed variables. Complementary, general linear models with the same design were used to test the effects of tree species, sites (both fixed factors), and replica (random factor), with tree species $\times$ replica nested in location, on BA, TD, DBH, DH and litterfall variables. The interaction (between the two fixed factors) for each variable was also analyzed. For variables with significant interactions, one-way ANOVAs were also performed to evaluate the effects of each factor separately. After all these analyses, a post hoc Tukey test (honest significant difference) at $p<0.05$ was applied to mean comparisons. Normality and homoscedasticity were previously checked by KolmogorovSmirnov and Levene tests, respectively, and variables that did not meet the assumptions were $\log (\mathrm{y}), \log (\mathrm{y}+1)$ or square root transformed. All statistical analyses were performed using Statgraphics Centurion XVI Version 16.1.11 (StatPoint Technologies, Warrenton, VA) package.

Complementary, two multivariate analyses were applied for physical and chemical mineral soil properties: (1) a principal component analyses (PCA) was performed to explore potential similarities among forest types and sites, as well as to analyze the influence of different soil properties on the plot ordination pattern; and (2) a multi-response permutation procedure (MRPP) was performed for a comparison among sites $\times$ forest type combinations, based on Euclidean distance and using " $\mathrm{T}$ " statistic, $p$ value and " $\mathrm{A}$ " for its evaluation (McCune and Grace 2002). The "T" of MRPP describes the separation between the groups (the more negative the value of "T", the stronger the separation) and has an associated $p$ value determined by numerical integration of the Pearson type III distribution. In MRPP, within-group homogeneity is measured as the chance-corrected within-group agreement (A), when: (1) all items are identical within groups, then $\mathrm{A}=1$ (perfect association); (2) heterogeneity within groups equals expectation by chance, then $\mathrm{A}=0$ (no association between sample units and defined groups); and (3) there is less agreement within groups than expected by chance, then $\mathrm{A}<0$ (McCune and Grace 2002). We used the PC-ORD (McCune and Mefford 1999) for multivariate analyses.

\section{Results}

\subsection{Litterfall measurements and forest structure}

Basal area and tree density showed significant differences among forest types, with lower values in $\mathrm{Np}$ $\left(66.5 \mathrm{~m}^{2} \mathrm{ha}^{-1}\right.$ basal area and 381 ind $\left.\mathrm{ha}^{-1}\right)$ than in $\mathrm{M}$ $\left(77.1 \mathrm{~m}^{2} \mathrm{ha}^{-1}\right.$ and 910 ind $\left.\mathrm{ha}^{-1}\right)$ and $\mathrm{Nb}\left(84.5 \mathrm{~m}^{2} \mathrm{ha}^{-1}\right.$ and 1239 ind $\mathrm{ha}^{-1}$ ). Differences were not detected between sites for tree density (Table 1), but were evident for basal area, with significantly lower values in coastal $\left(71.4 \mathrm{~m}^{2} \mathrm{ha}^{-1}\right)$ than mountain $\left(80.7 \mathrm{~m}^{2} \mathrm{ha}^{-1}\right)$ sites. However, basal area was significantly influenced by forest type $\times$ site interaction (Fig. 2a), as the three forest types in the mountain differed significantly between each other, but this was not the case on the coast. Moreover, basal area of $\mathrm{M}$ was significantly higher in the mountain site than on the coast, but differences between sites for this variable were not detected in $\mathrm{Np}$ and $\mathrm{Nb}$ (Fig. 2a). On the other hand, basal area and tree density did not differ significantly between $N$. pumilio and $N$. betuloides species in mixed forests with similar proportion of both species, although $N$. betuloides presented slightly lower basal area and quantity of trees than $N$. pumilio (Table 2). Neither of these differences were found between sites (Table 2), but mountains presented slightly higher basal area and density than coasts. Interactions were not significant either, but there was an effect of the nested random factor for both variables.

Diameter at breast height (DBH) and dominant height (DH) presented significant differences among forests types, with lower values in $\mathrm{Nb}(37.5 \mathrm{~cm}$ and $15.9 \mathrm{~m})$ than in $\mathrm{M}$ $(47.9 \mathrm{~cm}$ and $17.7 \mathrm{~m})$ and $\mathrm{Np}(63.2 \mathrm{~cm}$ and $21.9 \mathrm{~m})$. Meanwhile, differences were not detected between sites in either parameter (Table 1). Interactions were not significant either, but there was an effect of the nested random factor for DBH.

Litterfall also differed significantly among the studied forests types and sites. Np produced higher amounts of litterfall (2.31 tha $\left.\mathrm{hear}^{-1}\right)$ than $\mathrm{M}\left(1.70 \mathrm{t} \mathrm{ha}^{-1}\right.$ year $\left.^{-1}\right)$ and $\mathrm{Nb}$ $\left(1.13 \mathrm{t} \mathrm{ha}^{-1}\right.$ year $\left.^{-1}\right)$. On the other hand, litterfall was higher in the coast $\left(2.02 \mathrm{t} \mathrm{ha}^{-1}\right.$ year $\left.^{-1}\right)$ than in mountain sites $\left(1.40 \mathrm{t} \mathrm{ha}^{-1}\right.$ year $\left.^{-1}\right)$ (Table 1). However, these results were 
Table 1 General linear model analysis for a mixed model nested ANOVA-type design, testing for the effects of forest type ( $N p$ mixed forests dominated by Nothofagus pumilio, $M$ mixed forests with similar proportion of $N$. pumilio and $N$. betuloides, $N b$ mixed forests dominated by Nothofagus betuloides) and sites (COA coast, $M O U$ mountain) as fixed factors, and replica as random factor, on the forest structure of the study areas in Tierra del Fuego. $B A$ basal area, $T D$ tree density, $D B H$ diameter at breast height, $D H$ dominant height, $L$ litterfall. F (p) Fisher statistic with probability in parentheses. Different letters show differences by Tukey test at $\mathrm{p}<0.05$

\begin{tabular}{|c|c|c|c|c|c|c|}
\hline Main factors & & $\mathrm{BA}\left(\mathrm{m}^{2} \mathrm{ha}^{-1}\right)$ & TD (ind ha ${ }^{-1}$ ) & $\mathrm{DBH}(\mathrm{cm})$ & $\mathrm{DH}(\mathrm{m})$ & $\mathrm{L}\left(\mathrm{t} \mathrm{ha}{ }^{-1}\right.$ year $\left.^{-1}\right)$ \\
\hline \multirow[t]{3}{*}{ Forest type } & $\mathrm{Np}$ & $66.5 \mathrm{a}$ & $381 \mathrm{a}$ & $63.18 \mathrm{~b}$ & $21.97 \mathrm{~b}$ & $2.31 \mathrm{c}$ \\
\hline & M & $77.1 \mathrm{ab}$ & $910 \mathrm{ab}$ & $47.97 \mathrm{ab}$ & $17.65 \mathrm{ab}$ & $1.70 \mathrm{~b}$ \\
\hline & $\mathrm{Nb}$ & $84.5 \mathrm{~b}$ & $1239 \mathrm{~b}$ & $37.54 \mathrm{a}$ & $15.93 \mathrm{a}$ & $1.13 \mathrm{a}$ \\
\hline \multirow[t]{2}{*}{ Site } & $\mathrm{COA}$ & $71.4 \mathrm{a}$ & 790 & 47.41 & 18.73 & $2.02 \mathrm{~b}$ \\
\hline & MOU & $80.7 \mathrm{~b}$ & 896 & 51.72 & 18.31 & $1.40 \mathrm{a}$ \\
\hline \multicolumn{7}{|l|}{ Tested effects } \\
\hline Forest type & $\mathrm{F}(\mathrm{p})$ & $11.25(0.022 *)$ & $7.35(0.045 *)$ & $7.09(0.048 *)$ & $11.23\left(0.023^{*}\right)$ & $102.49(<0.001 *)$ \\
\hline Site & $\mathrm{F}(\mathrm{p})$ & $9.09(0.039 *)$ & $0.24(0.650)$ & $0.15(0.555)$ & $0.15(0.715)$ & $84.76(0.001 *)$ \\
\hline Forest type $\times$ Site & $\mathrm{F}(\mathrm{p})$ & $9.02(0.032 *)$ & $0.64(0.622)$ & $0.08(0.922)$ & $1.64(0.302)$ & $16.15(0.012 *)$ \\
\hline Forest type $\times$ Replica (Site) & $\mathrm{F}(\mathrm{p})$ & $0.62(0.654)$ & $1.28(0.289)$ & $6.75(0.002 *)$ & $1.10(0.365)$ & $5.37(0.001 *)$ \\
\hline
\end{tabular}

*Significant results $(\mathrm{p}<0.05)$

influenced significantly by forest type $\times$ site interaction (Fig. 2), because only Np litterfall differed significantly between coast and mountain sites (Fig. 2b). While the three forest types differed significantly among themselves in coast sites, $\mathrm{M}$ did not significantly differ from $\mathrm{Np}$ and $\mathrm{Nb}$ in mountain sites (Fig. 2b). Moreover, litterfall was also affected by nested random factors. Regarding mixed forests with similar proportion of both species, litterfall was significantly different for both tree species, with $N$. pumilio (1.16 $\mathrm{t} \mathrm{ha}^{-1}$ year ${ }^{-1}$ ) presenting higher values than $N$. betuloides $\left(0.54 \mathrm{t} \mathrm{ha}^{-1}\right.$ year $\left.^{-1}\right)$. Also, differences in litterfall between sites were detected because values were lower on the coast $\left(0.70 \mathrm{t} \mathrm{ha}^{-1}\right.$ year $\left.^{-1}\right)$ than in the mountains (1.01 tha hear $^{-1}$ ), and there was no interaction between these two main factors (Table 2).

\subsection{Soil chemical and physical parameters}

Among the mineral soil chemical properties analyzed, CEC and $\mathrm{pH}$ were the only parameters that presented significant differences by forest type. CEC was significantly higher in
$\mathrm{Np}$ (34.46 meq $\left.100 \mathrm{~g}^{-1}\right)$ than in Nb (28.70 meq $\left.100 \mathrm{~g}^{-1}\right)$, with intermediate values for $\mathrm{M}\left(31.07 \mathrm{meq} 100 \mathrm{~g}^{-1}\right)$. The same gradient was observed for $\mathrm{pH}$ : $\mathrm{Np}(4.9)>\mathrm{M}(4.3)>\mathrm{Nb}$ (3.7) (Table 3). Regarding sites, significant differences were found for $\mathrm{P}, \mathrm{C} / \mathrm{P}, \mathrm{CEC}$ and $\mathrm{pH}$ (Table 3 ). While $\mathrm{P}$ was significantly higher on the coast $(36.82 \mathrm{ppm})$ than in the mountains (8.13 ppm), C/P, CEC and $\mathrm{pH}$ exhibited an inverse response, with higher values in mountains than on the coast (281.2, $37.51 \mathrm{meq} 100 \mathrm{~g}^{-1}$ and 4.5 in mountain vs. 58.2, $25.32 \mathrm{meq}$ $100 \mathrm{~g}^{-1}$ and 4.1 in coast, respectively). A unique significant interaction was detected for $\mathrm{pH}$, as all forest types had significantly different $\mathrm{pH}$ values in the coast, but $\mathrm{M}$ and $\mathrm{Nb}$ had similar $\mathrm{pH}$ values in the mountain (Fig. 2c). Similarly, M stands differed significantly between coast and mountain, while the other forest types showed similar values between sites. Furthermore, there were no effects of the nested random factors except with $\mathrm{C} / \mathrm{P}$.

In relation to chemical storage, there were no significant differences regarding forests type (Table 4), site, interactions or nested random factor, except for $\mathrm{P}$ storage at different sites,
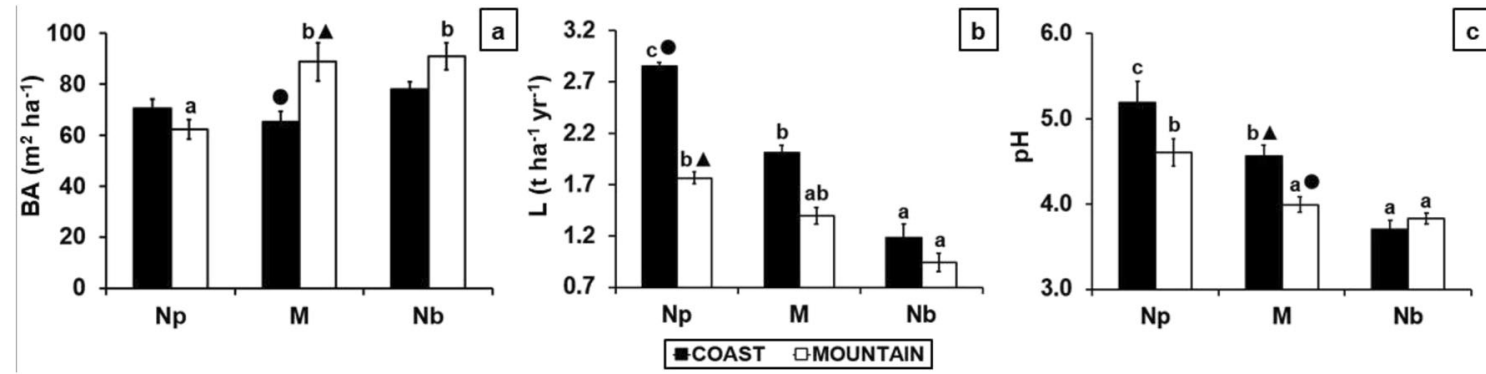

Fig. 2a-c Interactions corresponding to Tables 1 and 2. a Basal area $\left(\mathrm{m}^{2} \mathrm{ha}^{-1}\right)$, b Litterfall $\left(\mathrm{t} \mathrm{ha}^{-1}\right.$ year $\left.^{-1}\right)$, c $\mathrm{pH}$. Different letters and symbols indicate significant differences by Tukey test $(p<0.05)$ : lower case for comparisons among forest types ( $N p$ mixed forests dominated by Nothofagus pumilio, $M$ mixed forests with similar proportion of

$N$. pumilio and $N$. betuloides, $N b$ mixed forests dominated by Nothofagus betuloides) at each site; symbols $\boldsymbol{\Delta}$ and $\bullet$ for comparisons between locations (coast, mountain) at each forest type. Bars Standard error 
Table 2 General linear model analysis for a mixed model nested ANOVA-type design, testing for the effects of species ( N. pumilio and $N$. betuloides) and site as fixed factors, and replica as random factor, on the forest structure of mixed forests with similar proportion of both species. F (p) Fisher statistic with probability in parentheses. Different letters show differences by Tukey test at $\mathrm{p}<0.05$.

\begin{tabular}{|c|c|c|c|c|c|c|}
\hline Main factors & & $\mathrm{BA}\left(\mathrm{m}^{2} \mathrm{ha}^{-1}\right)$ & TD (ind ha ${ }^{-1}$ ) & $\mathrm{DBH}(\mathrm{cm})$ & $\mathrm{DH}(\mathrm{m})$ & $\mathrm{L}\left(\mathrm{t} \mathrm{ha} \mathrm{yr}^{-1}\right)$ \\
\hline \multirow[t]{2}{*}{ Species } & N. pumilio & 43.5 & 683 & 45.59 & 18.0 & $1.16 \mathrm{~b}$ \\
\hline & $N$. betuloides & 33.6 & 227 & 53.40 & 18.6 & $0.54 \mathrm{a}$ \\
\hline \multirow[t]{2}{*}{ Site } & $\mathrm{COA}$ & 32.7 & 366 & 54.37 & 17.4 & $0.70 \mathrm{a}$ \\
\hline & MOU & 44.4 & 544 & 44.65 & 19.3 & $1.01 \mathrm{~b}$ \\
\hline \multicolumn{7}{|l|}{ Tested effects } \\
\hline Species & $\mathrm{F}(\mathrm{p})$ & $0.49(0.555)$ & $2.17(0.278)$ & $0.86(0.451)$ & $0.19(0.703)$ & $86.93(0.011 *)$ \\
\hline Site & $\mathrm{F}(\mathrm{p})$ & $0.69(0.494)$ & $0.33(0.622)$ & $1.34(0.366)$ & $1.83(0.319)$ & $22.02(0.042 *)$ \\
\hline Species $\times$ Site & $\mathrm{F}(\mathrm{p})$ & $0.28(0.647)$ & $0.07(0.816)$ & $1.28(0.375)$ & $0.17(0.721)$ & $16.67(0.055)$ \\
\hline Species $\times$ Replica (Site) & $\mathrm{F}(\mathrm{p})$ & $6.19(0.005 *)$ & $4.68(0.016 *)$ & $3.78(0.333)$ & $0.61(0.548)$ & $1.95(0.158)$ \\
\hline
\end{tabular}

*Significant results $(\mathrm{p}<0.05)$

with significantly higher values on the coast $\left(4.8 \mathrm{Mg} \mathrm{ha}^{-1}\right)$ than in the mountains $\left(1.1 \mathrm{Mg} \mathrm{ha}^{-1}\right)$.

For the physical soil properties, there were no effects of forest type on all variables (Table 5). However, sites had a significant effect on SM (coast $=13.4 \%<$ mountain $=57 \%$ ) and $\mathrm{R}$ (coast $=474.2$ Newton $\mathrm{cm}^{-2}>$ mountain $=168.8$ Newton $\mathrm{cm}^{-2}$ ). The interaction between fixed factors had no effect on physical soil properties, or nested random factors.

Finally, soil temperature generally showed higher values on the coast than in the mountains (Fig. 3), with lowest values, close to $0{ }^{\circ} \mathrm{C}$, during June and July for $\mathrm{Np}$ in the mountain. However, those minimum values were not observed in other forest types or sites. The greatest variation in soil temperature occurred in Np during February (average temperature $\sim 7{ }^{\circ} \mathrm{C}$ in both coast and mountain sites), in $\mathrm{M}$ during January on the coast $\left(\sim 7.5^{\circ} \mathrm{C}\right)$, and during March in the mountain $\left(\sim 6^{\circ} \mathrm{C}\right)$, and in $\mathrm{Nb}$ during January $\left(\sim 6.9^{\circ} \mathrm{C}\right.$ in both coast and mountain sites) (Fig. 3a-c).

PCA analysis clearly separated two groups of soils: coastal and mountain sites, with few differentiations among forest types (Fig. 4). Axis 1 explained $39.3 \%$ of the variance and Axis 2 added $20.7 \%$ of the variance. Axis 1 mostly represented a gradient from sand soils and high N, SOC, SOM and $\mathrm{CEC}$, to silt-clay soils with high $\mathrm{SD}$, being more related to
Table 3 General linear model analysis for a mixed model nested ANOVA-type design, testing for the effects of forest type and site as fixed factors, and replica as random factor, on the chemical parameters of Nothofagus forest mineral soils. SOM= soil organic matter concentration, $S O C$ soil organic carbon concentration, $N$ nitrogen concentration, $P$ phosphorus concentration, $C / N$ carbon/nitrogen ratio, $C / P$ carbon/ phosphorus ratio, CEC cation exchange capacity, $\mathrm{pH}$. P, CEC and $\mathrm{pH}$ were transformed by $\log (\mathrm{Y})$ to accomplish assumptions, but not transformed averages are presented in the table. F (p) Fisher statistic with probability in parentheses. Different letters show differences by Tukey test at $\mathrm{p}<0.05$.

\begin{tabular}{|c|c|c|c|c|c|c|c|c|c|}
\hline Main factors & & $\operatorname{SOM}(\%)$ & $\operatorname{SOC}(\%)$ & $\mathrm{N}(\%)$ & $\mathrm{P}(\mathrm{ppm})$ & $\mathrm{C} / \mathrm{N}$ & $\mathrm{C} / \mathrm{P}$ & $\begin{array}{l}\text { CEC } \\
\left(\text { meq } 100 \mathrm{~g}^{-1}\right)\end{array}$ & $\mathrm{pH}$ \\
\hline \multirow[t]{3}{*}{ Forest type } & $\mathrm{Np}$ & 16.8 & 9.75 & 0.81 & 35.54 & 12.05 & 195.2 & $34.46 \mathrm{~b}$ & $4.9 \mathrm{c}$ \\
\hline & M & 15.85 & 9.19 & 0.73 & 16.64 & 12.42 & 148.7 & $31.07 \mathrm{ab}$ & $4.3 \mathrm{~b}$ \\
\hline & $\mathrm{Nb}$ & 17.01 & 9.87 & 0.81 & 15.25 & 12.13 & 165.3 & $28.70 \mathrm{a}$ & $3.7 \mathrm{a}$ \\
\hline \multirow[t]{2}{*}{ Site } & $\mathrm{COA}$ & 14.88 & 8.63 & 0.70 & $36.82 \mathrm{~b}$ & 12.37 & $58.2 \mathrm{a}$ & $25.32 \mathrm{a}$ & $4.1 \mathrm{a}$ \\
\hline & $\mathrm{MOU}$ & 18.22 & 10.57 & 0.88 & $8.13 \mathrm{a}$ & 12.04 & $281.2 \mathrm{~b}$ & $37.51 \mathrm{~b}$ & $4.5 \mathrm{~b}$ \\
\hline \multicolumn{10}{|l|}{ Tested effects } \\
\hline Forest type & $\mathrm{F}(p)$ & $0.23(0.808)$ & $0.23(0.806)$ & $0.35(0.727)$ & $3.91(0.114)$ & $3.58(0.129)$ & $0.03(0.970)$ & $8.63\left(0.035^{*}\right)$ & $\begin{array}{l}124.22 \\
\quad\left(<0.001^{*}\right)\end{array}$ \\
\hline Site & $\mathrm{F}(p)$ & $4.92(0.091)$ & $4.87(0.091)$ & $6.89(0.058)$ & $\begin{array}{l}18.52 \\
\quad(0.013)^{*}\end{array}$ & $7.46(0.052)$ & $\begin{array}{l}16.16 \\
\quad\left(0.016^{*}\right)\end{array}$ & $\begin{array}{l}114.18 \\
\quad(<0.001 *)\end{array}$ & $28.18\left(0.006^{*}\right)$ \\
\hline $\begin{array}{l}\text { Forest type } \\
\quad \times \text { Site }\end{array}$ & $\mathrm{F}(p)$ & $0.55(0.614)$ & $0.54(0.621)$ & $1.06(0.428)$ & $2.67(0.183)$ & $2.78(0.175)$ & $1.74(0.286)$ & $0.00(0.999)$ & $16.33(0.012 *)$ \\
\hline $\begin{array}{l}\text { Forest type } \\
\quad \times \text { Replica } \\
\text { (Site) }\end{array}$ & $\mathrm{F}(p)$ & $0.51(0.730)$ & $0.51(0.727)$ & $0.49(0.740)$ & $1.97(0.114)$ & $0.56(0.694)$ & $\begin{array}{l}3.66 \\
\quad(0.012 *)\end{array}$ & $0.14(0.967)$ & $0.25(0.908)$ \\
\hline
\end{tabular}

*Significant results $(\mathrm{p}<0.05)$ 
Table 4 General linear model analysis for a mixed model nested ANOVA-type design, testing for the effects of forest type and site as fixed factors, and replica as random factor, on the chemical storage of Nothofagus forest mineral soils. $\mathrm{N}$ and $\mathrm{P}$ were transformed by $\log (\mathrm{Y})$ to accomplish assumptions, but not transformed averages are presented in the table. F (p) Fisher statistic with probability in parentheses. Different letters show differences by Tukey test at $p<0.05$.

\begin{tabular}{llllll}
\hline Main factors & & $\begin{array}{l}\mathrm{SOM} \\
\left(\mathrm{Mg} \mathrm{ha}^{-1}\right)\end{array}$ & $\begin{array}{l}\mathrm{SOC}(\mathrm{Mg} \mathrm{C} \\
\left.\mathrm{ha}^{-1}\right)\end{array}$ & $\begin{array}{l}\mathrm{N} \\
\left(\mathrm{Mg} \mathrm{ha}^{-1}\right)\end{array}$ & $\mathrm{P}\left(\mathrm{Mg} \mathrm{ha}^{-1}\right)$ \\
\hline Forest type & $\mathrm{Np}$ & 56.9 & 32.4 & 1.79 & 4.9 \\
& $\mathrm{M}$ & 54.1 & 28.6 & 1.41 & 2.1 \\
& $\mathrm{Nb}$ & 58.5 & 33.3 & 1.84 & 1.8 \\
Site & $\mathrm{COA}$ & 52.6 & 26.5 & 1.27 & $4.8 \mathrm{~b}$ \\
& $\mathrm{MOU}$ & 60.4 & 36.4 & 2.09 & $1.1 \mathrm{a}$ \\
Tested effects & & & & & \\
Forest type & $\mathrm{F}(\mathrm{p})$ & $0.09(0.914)$ & $0.16(0.855)$ & $0.21(0.816)$ & $0.72(0.542)$ \\
Site & $\mathrm{F} \mathrm{(p)}$ & $0.84(0.412)$ & $1.89(0.241)$ & $3.12(0.152)$ & 20.80 \\
& & & & & $\left(0.010^{*}\right)$ \\
Forest type $\times$ Site & $\mathrm{F} \mathrm{(p)}$ & $0.00(0.997)$ & $0.05(0.948)$ & $0.12(0.891)$ & $3.97(0.112)$ \\
Forest type $\times$ Replica (Site) & $\mathrm{F} \mathrm{(p)}$ & $1.23(0.309)$ & $0.88(0.484)$ & $0.89(0.478)$ & $2.11(0.094)$ \\
\hline
\end{tabular}

*Significant results $(\mathrm{p}<0.05)$ the variations. Meanwhile, Axis 2 represented a gradient from high $\mathrm{P}, \mathrm{R}, \mathrm{pH}$ and $\mathrm{T}$, to low $\mathrm{SM}$ and $\mathrm{C} / \mathrm{P}$, being more related to the forest types. MRPP confirmed significant statistical differences among site $\times$ forest type combinations $(T=-13.28$; $p<0.001 ; \mathrm{A}=0.44$ ), with significant differences in most comparisons between groups, except for $\mathrm{Nb}$ and $\mathrm{M}$ coastal sites $(\mathrm{T}=0.23 ; p=0.441 ; \mathrm{A}=-0.01), \mathrm{Nb}$ and $\mathrm{M}$ in mountain sites $(\mathrm{T}=0.756 ; p=0.791 ; \mathrm{A}=-0.018)$, and $\mathrm{Np}$ and $\mathrm{M}$ in mountain sites $(\mathrm{T}=-0.673 ; p=0.179 ; \mathrm{A}=0.02)$.

\subsection{Soil properties relationships}

When we related particular nutrients and physical soil properties (Fig. 5), we observed a negative correlation between $\mathrm{N}$ and SOC with clay, with lower N and SOC content as the clay proportion in the soil increased (Fig. 5a,b). The soils of mountain sites presented high $\mathrm{N}$ and SOC while clay proportion decreased, and the coast sites had low N and SOC while clay proportion increased. Conversely, we observed a positive correlation between $\mathrm{C} / \mathrm{N}$ ratio and clay proportion (high levels in coastal sites) (Fig. 5c). The correlation between SOC and N was also positive, but exhibiting lower values in coast than in mountain forests (Fig. 5d). P availability increased while decreasing the content of SOC (Fig. 5e), highlighting the high value of $\mathrm{P}$ and the low value of SOC in coast forests. $\mathrm{P}$ availability also increased as the proportion of clay increased (Fig. $5 \mathrm{f}$ ), with lower values in mountain than in coast forests, which also coincides with the high litterfall biomass of $\mathrm{Np}$ on the coast. When $\mathrm{P}$ was analyzed in relation to $\mathrm{pH}$, mountain forests had always lower values of $\mathrm{P}$ than the soils on the coast, but $\mathrm{pH}$ values were similar between sites (Fig. $5 \mathrm{~g}$ ). P and $\mathrm{C} / \mathrm{N}$ ratio showed a positive correlation, with lower values in soils of mountain than of coastal sites (Fig. 5h). The above variables ( $\mathrm{pH}$ and $\mathrm{C} / \mathrm{N}$ ratio), together with $\mathrm{P}$, correlate positively
Table 5 General linear model analysis for a mixed model nested ANOVA-type design, testing for the effects of forest type and site as fixed factors, and replica as random factor, on physical parameters of Nothofagus forest mineral soils. $S D$ soil density, $S M$ soil moisture, $R$

\begin{tabular}{|c|c|c|c|c|c|c|c|}
\hline Main factors & & Clay $(\%)$ & Silt $(\%)$ & Sand $(\%)$ & $\mathrm{SD}\left(\mathrm{g} \mathrm{cm}^{-3}\right)$ & $\operatorname{SM}(\%)$ & $\mathrm{R}\left(\right.$ Newton $\left.\mathrm{cm}^{-2}\right)$ \\
\hline \multirow[t]{3}{*}{ Forest type } & $\mathrm{Np}$ & 4.2 & 13.2 & 82.6 & 0.70 & 31.4 & 392.8 \\
\hline & M & 4.1 & 11.8 & 84.1 & 0.76 & 34.9 & 288.3 \\
\hline & $\mathrm{Nb}$ & 3.8 & 10.8 & 85.4 & 0.73 & 39.3 & 250.5 \\
\hline \multirow[t]{2}{*}{ Site } & $\mathrm{COA}$ & 4.8 & 13.6 & 81.6 & 0.75 & $13.4 \mathrm{a}$ & $474.2 \mathrm{~b}$ \\
\hline & $\mathrm{MOU}$ & 3.3 & 10.4 & 86.3 & 0.71 & $57.0 \mathrm{~b}$ & $146.8 \mathrm{a}$ \\
\hline \multicolumn{8}{|l|}{ Tested effects } \\
\hline Forest type & $\mathrm{F}(\mathrm{p})$ & $0.09(0.913)$ & $1.49(0.329)$ & $0.67(0.563)$ & $0.18(0.839)$ & $0.70(0.548)$ & $4.42(0.097)$ \\
\hline Site & $F(p)$ & $4.21(0.109)$ & $5.97(0.071)$ & $5.64(0.076)$ & $0.38(0.569)$ & $194.24(<0.001)^{*}$ & $100.68(<0.001 *)$ \\
\hline Forest type $\times$ Location & $F(p)$ & $0.27(0.778)$ & $1.55(0.317)$ & $0.47(0.654)$ & $0.20(0.827)$ & $4.06(0.109)$ & $0.50(0.641)$ \\
\hline Forest type $\times$ Replica (Site) & $\mathrm{F}(\mathrm{p})$ & $1.17(0.335)$ & $1.02(0.407)$ & $1.32(0.277)$ & $1.18(0.332)$ & $0.91(0.463)$ & $1.21(0.319)$ \\
\hline
\end{tabular}

resistance to penetration.Silt, SM and R were transformed by $\log (\mathrm{Y})$ to accomplish assumptions, but not transformed averages are presented in the table. F (p) Fisher statistic with probability in parentheses. Different letters in each column show differences by Tukey test at $p<0.05$.

*Significant results $(\mathrm{p}<0.05)$ 

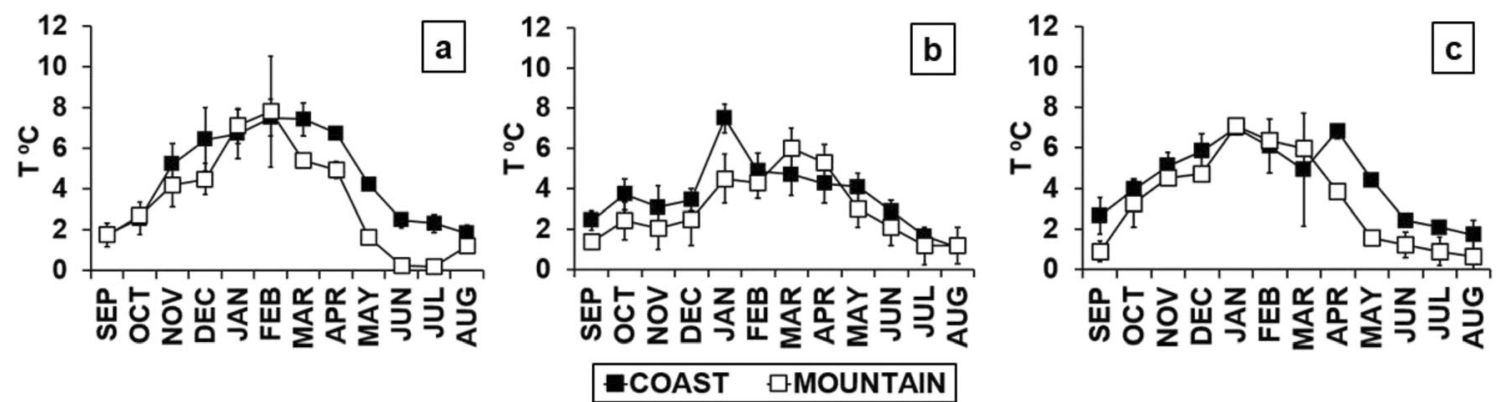

Fig. 3a-c Mean soil temperature values registered between in September 2013 to August 2014 in different forests types, in coast and mountain sites. a Mixed forests dominated by $N$. pumilio, $\mathbf{b}$ mixed forests with similar proportion of $N$. pumilio and $N$. betuloides, and $\mathbf{c}$ mixed forests dominated by $N$. betuloides, in coast and mountain. Bars Standard error with the high litterfall production of coast forests, despite the fact that the basal area of the coast is significantly lower. Finally, $\mathrm{N}$ and $\mathrm{C} / \mathrm{P}$ showed a positive correlation as higher values of $\mathrm{N}$ were recorded in mountain sites where the $\mathrm{C} / \mathrm{P}$ ratio was also high (Fig. 5i).

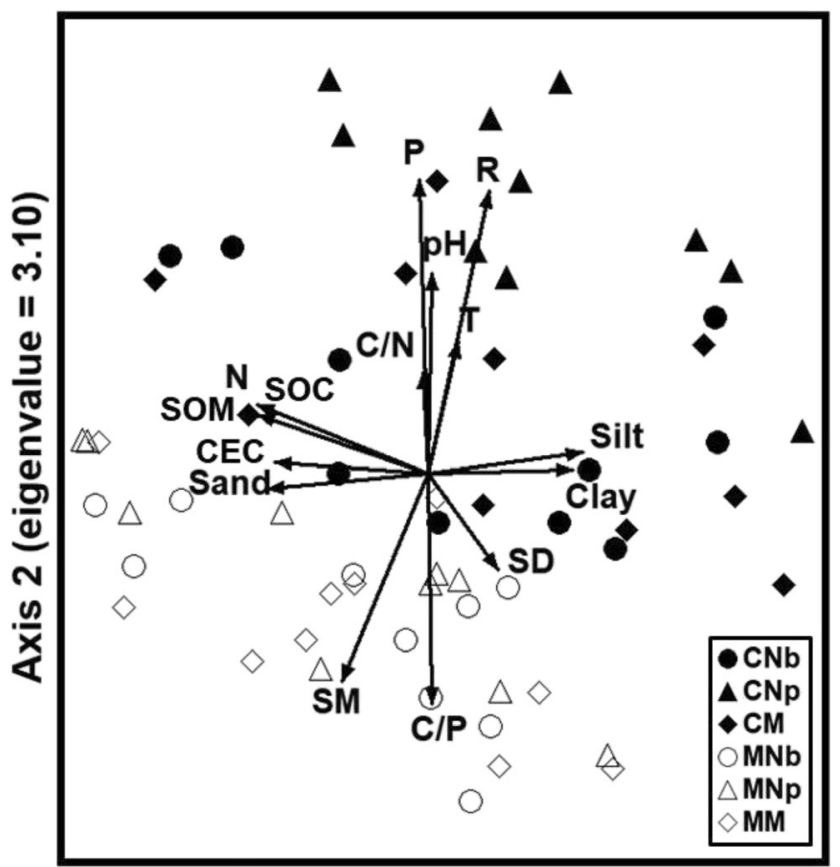

Axis 1 (eigenvalue $=\mathbf{5 . 9 1}$ )

Fig. 4 Principal component analyses (PCA) for chemical and physical properties of forest mineral soils of mixed Nothofagus forests at different sites. SOM Soil organic matter concentration, SOC soil organic carbon concentration, $C E C$ cation exchange capacity, $P$ phosphorus concentration, $S D$ soil density, $R$ resistance to penetration, $S M$ soil moisture, $T$ soil temperature, $N$ nitrogen concentration, $C / N$ carbon/nitrogen ratio, $C / P$ carbon/phosphorus ratio, $C N b$ coast forests dominated by $N$. betuloides, $C N p$ coast forests dominated by $N$. pumilio, $C M$ coast mixed forests with similar proportion of $N$. pumilio and $N$. betuloides, $M N b$ mountain forests dominated by $N$. betuloides, $M N p$ mountain mixed forests dominated by $N$. pumilio, $M M$ mountain mixed forests with similar proportion of $N$. pumilio and $N$. betuloides

\section{Discussion}

\subsection{Litterfall in relation to forest structure}

Litterfall input depends significantly on the foliar traits and phenology of each species (i.e., higher litterfall input in canopies dominated by deciduous species). Although forest structure also differed with canopy composition, the trend was inverse (i.e., highest litterfall in forest types with lowest basal area and density). The high litter input in $\mathrm{CNp}$ may be related to the site quality rather than to basal area of sites, where tree height is above $20 \mathrm{~m}$ (Toro Manríquez et al. 2016) corresponding to a high site quality class (I-II, according to Martínez Pastur et al. 1997), which is associated with potentially highly productive forests in South Patagonia (Martínez Pastur et al. 2000). Similarly, high quality sites have been correlated with higher litter production for other Nothofagus forests (Bahamonde et al. 2015). Our results showed that litter input depends significantly on site factors, and that, moreover, canopy composition interacts with site, jointly determining the amount of biomass available for decomposition cycle and nutrient turnover (Moretto and Martínez Pastur 2014).

\subsection{Canopy composition influences on mineral soil conditions}

We assessed the effects of three forest types with different proportions of deciduous-evergreen canopies on physicochemical soil properties. We expected that deciduous and evergreen forests present different soil characteristics, mainly considering the foliar traits and litter quality of each tree species, which can influence soil nutrient availability (Scheibe et al. 2015). Our results showed that canopy-layer composition strongly influences $\mathrm{CEC}$ and $\mathrm{pH}$ at our study sites, which were higher in $\mathrm{Np}$. Moreover, these variables (CEC and $\mathrm{pH}$ ) were directly related among themselves, and also with $\mathrm{P}$ content. However, the results of available P content should be interpreted carefully considering the methodological bias when determining available $\mathrm{P}$ in soils with low $\mathrm{pH}$ values. 

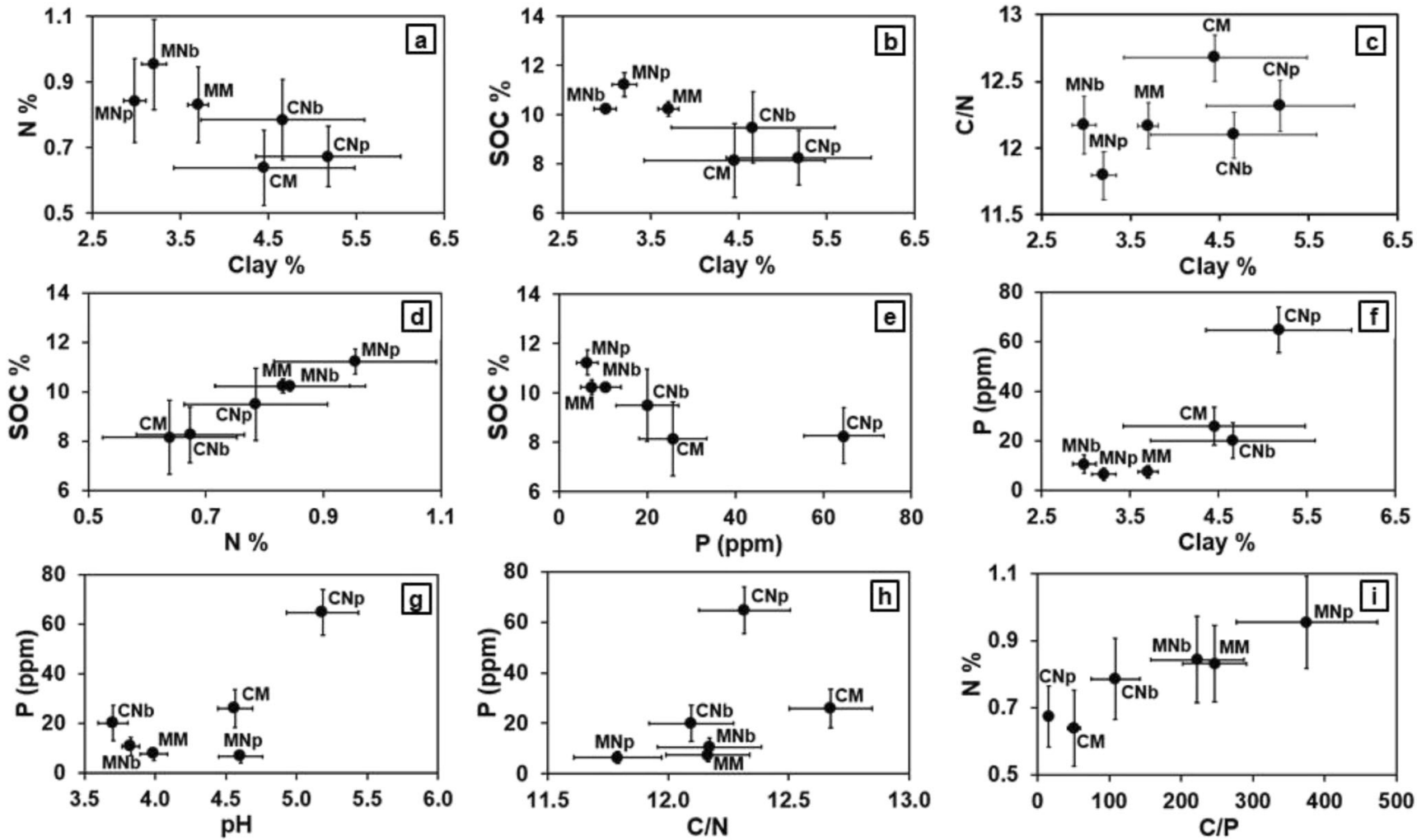

Fig. 5 Relationship between mean values of a N\% and clay $\%$, b SOC $\%$ and clay $\%, \mathbf{c} \mathrm{C} / \mathrm{N}$ and clay $\%, \mathbf{d ~ S O C} \%$ and $\mathrm{N} \%$, e SOC $\%$ and $\mathrm{P}(\mathrm{ppm}), \mathbf{f}$ $\mathrm{P}(\mathrm{ppm})$ and clay \%, $\mathbf{g} \mathrm{P}(\mathrm{ppm})$ and $\mathrm{pH}, \mathbf{h} \mathrm{P}(\mathrm{ppm})$ and $\mathrm{C} / \mathrm{N}$, and $\mathbf{I} \mathrm{N} \%$ and $\mathrm{C} / \mathrm{P}$ (meq/100 g). $N$ nitrogen concentration, TOC total organic carbon concentration, $P$ phosphorus concentration, $C / N$ carbon/nitrogen ratio, $C E C$ cation exchange capacity, $C N b$ coast forests dominated by
$N$. betuloides, CNp coast forests dominated by $N$. pumilio, CM coast mixed forests with similar proportion of $N$. pumilio and $N$. betuloides, $M N b$ mountain forests dominated by $N$. betuloides, $M N p$ mountain mixed forests dominated by $N$. pumilio, $M M$ mountain mixed forests with similar proportion of N. pumilio and N. betuloides. Bars Standard error

Low CEC values indicate soils with low ability to retain nutrients, sandy texture or poor in organic matter (Thiers and Gerding 2007). On the other hand, the significantly lower $\mathrm{pH}$ in $\mathrm{Nb}$ than in $\mathrm{Np}$ was evidence of an incipient soil acidification process, which can affect nutrient availability, for example, P content (Chen et al. 2016; Mao et al. 2017). Accordingly, we could consider a more fertile soil in $\mathrm{Np}$ than in $\mathrm{Nb}$, with intermediate values for $\mathrm{M}$. Indeed, Romanya et al. (2005) described similar differences among soil nutrients for both Nothofagus species in pure forests of Tierra del Fuego, where higher amounts of available $\mathrm{P}$ and highest organic matter turnover rates are observed in $N$. pumilio, than in $N$. betuloides forests. Despite the lack of statistical significance, in our study the $\mathrm{P}$ content recorded in $\mathrm{Np}$ was double the values in $\mathrm{Nb}$ forests. Since the availability of nutrients in the soil depends not only on the quantity but also on the quality of the litter and the climatic conditions within the forest (Rothe and Binkley 2001), leaves of $\mathrm{Nb}$ decompose more slowly than leaves of Np (Frangi et al. 2005), which could explain the observed difference in $\mathrm{P}$ concentrations. Unfortunately, the nutrition status or requirements for this Nothofagus species are unknown, so we cannot infer a possible limitation to tree growth due to low $\mathrm{P}$ concentration in some forest types. However, the health of the forest structure was similar among the studied stands and we did not observe signs of malnutrition, diseases, lack of natural regeneration, etc., in poor $\mathrm{P}$ concentration soils $(\mathrm{Nb}$ or $\mathrm{M})$. Further studies and more replicates are necessary to fully understand this canopy-soil relationship in a broader spatial context. Similarly, future studies must include analysis of the organic layer, which may make a large contribution to carbon storage and $\mathrm{P}$ dynamics from topsoil to deeper horizons.

MRPP detected similarities between $\mathrm{Nb}$ and $\mathrm{M}$ in coast and mountains. This could indicate that $M$ forest soils resemble $\mathrm{Nb}$ to some extent, when all the variables (soil + environment) are considered. Other biotic factors (microbiological communities, soil respiration, and nutrient dynamics) and environmental interactions (Lucas-Borja et al. 2012) should be analyzed to better understand the influence of canopy composition on the soil in these broadleaf temperate forests. The simple number of tree species is not the only factor driving nutrient release and decomposition processes; key groups of decomposer fauna as well as the functional traits of tree species, are also decisive (Jacob et al. 2009).

In contrast to nutrients, physical properties do not seem to be affected by canopy composition. The soil textural class of 
all forest types was the same (sandy) and the soil moisture and density did not show significant differences among them. This lack of statistical difference, even in those variables that differ slightly among forest types as $\mathrm{R}$, could be due to the great spatial variability in soil characteristics, moisture and particle size in forests at the scale of a few square meters (Boyden et al. 2005). Also, there can be great variability of microclimatic conditions within a stand due to canopy gaps, shading, or wind protection from neighbors (Rao et al. 1997).

\subsection{Site influences on mineral soil conditions}

Our results suggest that site conditions strongly influence both physical and chemical mineral soil properties of mixed Nothofagus forest. Site conditions summarize climate, geographic location, and site quality variation, e.g., elevation and topography, which are two key factors influencing soil characteristics over the geographic range of Nothofagus genus (Thiers and Gerding 2007; Lucas-Borja et al. 2012). In our study, the coastal sites occupy lower elevation than mountain sites, and the slope and relief between coastal and mountain forests varied strongly according to the topography (e.g., more rugged terrain on mountain, less steep slopes on the coast). Frequently, high elevation lands (e.g., steep slopes) do not facilitate great depth of the mineral soils, but the thickness of leaf layer is increased compared to low elevation lands (Gerding and Thiers 2002). In terms of physical properties, differences between sites were mainly regarding soil texture: the soils of coastal forests had a greater proportion of silt + clay while the soils of the mountain forests were sandier. According to Parras-Alcántara et al. (2015), soil texture differences across the altitudinal gradient affect SOC content, but we did not find such an effect.

Climatic factors, mainly soil temperature and moisture, seem to play a dominant role over physical and chemical mineral soil properties. Temperature determines leaf rate decomposition, microbial activity involved in organic matter decomposition, and thus the rate of nutrient cycling (Rothe and Binkley 2001; Hättenschwiler et al. 2005; Lucas-Borja et al. 2012; Brunel et al. 2017). In accordance with this, climatic variables recorded in this study (e.g., soil temperature and moisture) were decisive in differentiating the plots in the PCA, by weighting the differences among sites. The warmer and drier soils recorded on the coast compared to mountain sites may be the result of a more open canopy cover, which allows a greater entrance of light to the forest floor (Ayres et al. 2009). This is following Toro Manríquez et al. (2016) and Mestre et al. (2017), who showed that canopy cover during the summer season in coastal Nothofagus forests turns out to be more open than mountain forest canopies.

The higher $\mathrm{N}$ concentration and storage values should be related to the soil organic matter as a source of available $\mathrm{N}$. Indeed, $\mathrm{N}$ and SOC were positively correlated, and both elements increased from the coast to the mountain following the same sequence: $\mathrm{Nb}<\mathrm{M}<\mathrm{Np}$. As $\mathrm{N}$ cycling is determined mainly by litterfall quality, it is controlled largely by vegetation composition. High $P$ value concentration in the coast could be related to cycling of this element in the organic layer, as stated by Romanya et al. (2005). However, as the present study did not assess the organic layer, understanding of $\mathrm{P}$ cycling is limited. Although recent geological processes in both coast and mountain sites were driven by glaciers, the high $P$ value in the coast could be related to the original soil material and more ancient geological processes (e.g., marine deposits). On the other hand, $\mathrm{P}$ in mineral soils in our study was negatively related to SOC. For this, a detailed investigation of $\mathrm{P}$ dynamics and bioavailability requires the identification of different forms of $\mathrm{P}$ in soils (Hou et al. 2018), which exceeds the objective of this work. Soil P supply is largely controlled by the multiple forms of $\mathrm{P}$ existing in the soils, which differ in their availability for plant uptake across time scales (Vitousek et al. 2010). Moreover, it should be considered that higher accumulation of $\mathrm{N}$ in soils can affect the availability of $\mathrm{P}$, changing the ion balance and the production of phosphates in the soils (Treseder and Vitousek 2001). In places with $P$ limitation, SOC allocation would bring more carbon uptake, which is an effective adaptive strategy under P limitation in older forests. Mountain forests can follow this strategy against $\mathrm{P}$ limitation, unlike coastal forests, which have higher $\mathrm{P}$ content compared to SOC (Wardle et al. 2005; Zhang et al. 2005).

The mineral soils of coastal sites were more compacted than in mountain sites according to the resistance to penetration measurements. This soil compaction was not evidenced by soil bulk density because it was evaluated in the upper layer of mineral soil (first $5 \mathrm{~cm}$ deep), while resistance to penetration indicated deep soil compaction in the A horizon (up to $30 \mathrm{~cm}$ deep). In the same way, resistance to penetration could not be strictly related to soil moisture as is usually cited by other authors (e.g., Utset and Cid 2001) since soil moisture was measured at $6 \mathrm{~cm}$ deep in this study. High soil compaction at greater depth could be due to greater root density in the coastal forest floor given the higher shrub abundance than in mountain forests (Mestre et al. 2017). According to Osman (2013) soil texture could also influence soil density (e.g., relatively more silt in soils of the coast), but significant differences in soil texture were not observed in our results. The relationship between $\mathrm{SOC}$ and clay showed that, with increasing clay, SOC decreases. Klein et al. (2008) concluded that long-term storage of SOC in the soil profile is affected mostly by clay content, which can explain the lower SOC content in coastal sites recorded in this study. In conclusion, sites determine major differences in the soil properties of these studied mixed Nothofagus forests associated mainly with elevation, topography, soil texture, temperature and soil moisture. Moreover, water soil content was four-fold higher in mountain than in coastal sites, which could explain the higher 
$\mathrm{CEC}$ and the lower $\mathrm{P}$ contents in the mountain sites. This is a prominent feature for these Nothofagus forests, as the carbon stock in these soils produced by organic matter is relatively abundant compared to those in other temperate forests in top soil $(0-30 \mathrm{~cm})$ (Bahamonde et al. 2012; Peri et al. 2015; Barré et al. 2017).

\subsection{Implications of mineral soil conditions on the dynamics of mixed forests}

In this study, high P content in $\mathrm{Np}$ forests could be understood as a significant contribution to better assimilation of nutrients available for tree seedlings and also for understory plant growth (Mestre et al. 2017). P is a vital nutrient for soil fertility and an important factor for natural tree regeneration and the coexistence of plant species (Liu et al. 2014).

The amount of resources required for seedling establishment and growth varies with species-specific traits (Carswell et al. 2012). Little is known about the nutritional requirements of deciduous and evergreen Nothofagus trees at the initial stages of regeneration. However, other authors argue that nutrient supply in the uppermost mineral soil layer should be preserved to sustain natural regeneration (Ibarra et al. 2007; Peña-Rodríguez et al. 2013).

We expected to find drastic differences in soil properties between Nothofagus forest with different canopy composition. However, the results obtained are not enough to identify key nutritional elements that could help to clarify the observed differences in natural regeneration process (data not shown), potential competition or coexistence between deciduous and evergreen tree species in each forest type.

Finally, we found by MRPP analyses that soils in M were more similar to soils of $\mathrm{Nb}$ in the coast, while mountain soils were more similar in both $\mathrm{Np}$ and $\mathrm{Nb}$. This contribution to soil properties could be reflected in the seedling establishment phase within the mixed forests. Future studies should consider variations in soil properties according to different exposures, latitudinal gradient (and associated climatic variations), litterfall chemical composition and other biological and ecological soil processes (e.g., microbial action, decomposition), humus thickness, weight and form, as well as the determination of other macronutrients such as $\mathrm{K}, \mathrm{Ca}, \mathrm{Mg}$.

\section{Conclusions}

In this study, mineral soil properties of Nothofagus mixed forests were influenced slightly by canopy-layer composition. Specifically CEC and $\mathrm{pH}$ were the variables most affected by tree species and litterfall input, which were higher in deciduous (Nothofagus pumilio) forests. On the other hand, our results suggest that it is important to consider organic $\mathrm{P}$ in future studies, including the evaluation of $\mathrm{P}$ fractions. The sites evaluated exhibited major differences, and also interact with canopy composition, associated with climatic variables and geographical conditions. However, it is important to note that this study evaluated only two replicas at the different sites. Therefore, our results should be considered carefully before generalizing to a broader context. Despite this, site conditions and canopy composition need be considered together to better understand the distribution of the Nothofagus species. This study contributes to knowledge about mineral soil in mixed broadleaf forests in the Southern Hemisphere.

Acknowledgments The authors gratefully thank the Centro Austral de Investigaciones Científicas (CADIC, CONICET) and Tierra del Fuego National Park (PNTDF) for their support during the realization of this work. We are grateful to Guillermo Martínez Pastur for the supervision, Luciana Mestre for help with the field sampling, and to the editors of Annals of Forest Science Journal (Erwin Dreyer, Chief Editor and Andreas Bolte, Associate Editor) and the anonymous reviewer, for valuable comments and suggestions that helped to significantly improve this manuscript.

Data availability The datasets are located at CADIC repository, or available from the corresponding author on reasonable request. The authors have requested permission to place data in the public repository SNDB (https://datos.sndb.mincyt.gob.ar/), but currently access to our data is only upon request.

\section{Compliance with ethical standards}

Conflict of interest The authors declare that they have no conflict of interest.

\section{References}

Augusto L, Ranger J, Ponette Q, Rapp M (2000) Relationships between forest tree species, stand production and stand nutrient amount. Ann For Sci 57:313-324. https://doi.org/10.1051/forest:2000122

Augusto L, Ranger J, Binkley D, Rothe A (2002) Impact of several common tree species of European temperate forests on soil fertility. Ann For Sci 59:233-253. https://doi.org/10.1051/forest:2002020

Ayres E, Steltzer H, Berg S, Wallenstein MD, Simmons BL, Wall DH (2009) Tree species traits influence soil physical, chemical, and biological properties in high elevation forests. PLoS One 4(6):e5964. https://doi.org/10.1371/journal.pone.0005964

Bahamonde HA, Peri PL, Alvarez R, Barneix A, Moretto A, Martínez Pastur G (2012) Litter decomposition and nutrients dynamics in Nothofagus antarctica forests under silvopastoral use in southern Patagonia. Agrofor Syst 84:345-360. https://doi.org/10.1007/ s10457-012-9479-7

Bahamonde HA, Peri PL, Martínez Pastur G, Monelos L (2015) Litterfall and nutrients return in Nothofagus antarctica forests growing in a site quality gradient with different management uses in southern Patagonia. Eur J For Res 134:113-124. https://doi.org/10.1007/ s10342-014-0837-z

Bahamonde HA, Martínez Pastur G, Lencinas MV, Soler Esteban R, Rosas YM, Ladd B, Duarte Guardia S, Peri PL (2018) The relative importance of soil properties and regional climate as drivers of productivity in southern Patagonia's Nothofagus antarctica forests. Ann for Sci 75:e-45. https://doi.org/10.1007/s13595-018-0725-7

Barré P, Durand H, Cl C, Meunier P, Montagne D, Castel G, Billiou D, Soucémarianadin L, Cécillon L (2017) Geological control of soil 
organic carbon and nitrogen stocks at the landscape scale. Geoderma 285:50-56. https://doi.org/10.1016/j.geoderma.2016.09.029

Bingham AH, Cotrufo MF (2016) Organic nitrogen storage in mineral soil: implications for policy and management. Sci Total Environ 551-552:116-126. https://doi.org/10.1016/j.scitotenv.2016.02.020

Binkley D, Giardina C (1998) Why do tree species affect soils? The warp and woof of tree-soil interactions. Biogeochemistry 42(1-2):89 106. https://doi.org/10.1023/A:1005948126251

Binkley D, Valentine D (1991) Fifty - year biogeochemical effects of green ash, white pine and Norway spruce in a replicated experiment. For Ecol Manag 40(1-2):13-25. https://doi.org/10.1016/03781127(91)90088-D

Bitterlich W (1984) The Relascope idea. Relative Measurements in Forestry. Commonwealth Agricultural Bureaux, London

Bouyoucos GJ (1936) Directions for making mechanical analysis of soils by the hydrometer method. Soil Sci 42:225-230. https://doi.org/10. 1097/00010694-193609000-00007

Boyden S, Binkley D, Senock R (2005) Competition and facilitation between Eucalyptus and nitrogen-fixing Falcataria in relation to soil fertility. Ecology 86(4):992-1001. https://doi.org/10.1890/040430

Boyle JR (2005) Forest soils. In: Hillel D (ed) Encyclopedia of soils in the environment. Elsevier, Oxford, pp 73-79. https://doi.org/10.1016/ B0-12-348530-4/00033-3

Bray RH, Kurtz LT (1945) Determination of total, organic, and available forms of phosphorus in soils. Soil Sci 59:39-45. https://doi.org/10. 1097/00010694-194501000-00006

Brunel C, Gros R, Ziarelli F, Farnet Da Silva AM (2017) Additive or nonadditive effect of mixing oak in pine stands on soil properties depends on the tree species in Mediterranean forests. Sci Total Environ 14:676-685. https://doi.org/10.1016/j.scitotenv.2017.03.023

Burgos J (1985) Clima del extremo austral de Sudamérica. In: Boelcke O, Moore DM, Roig FA (eds) Transecta botánica de la Patagonia austral. CONICET, Bueno Aires, pp 10-48

Carswell FE, Doherty JE, Allen RB, Brignall-Theyer ME, Richardson SJ, Wiser SK (2012) Quantification of the effects of above ground and below ground competition on growth of seedlings in a conifer angiosperm forest. For Ecol Manag 269:188-196. https://doi.org/10. 1016/j.foreco.2011.12.027

Chen H, Gurmesa GA, Zhang W, Zhu X, Zheng M, Mao Q, Zhang T, Mo $J$ (2016) Nitrogen saturation in humid tropical forests after 6 years of nitrogen and phosphorus addition: hypothesis testing. Funtional Ecol 30:305-313. https://doi.org/10.1111/1365-2435.12475

Collado L (2001) Los bosques de Tierra del Fuego: Análisis de su estratificación mediante imágenes satelitales para el inventario forestal de la provincia. Multequina 10:1-15

Contreras H, Borgel R, Quezada M, García de Cortázar V, Rojas M, Bitterlich W (1975) Informe de la primera etapa del proyecto sobre reforestación de la Precordillera Patagónica (Cuadrángulos Skyring y Rubens). Facultad de Ciencias Forestales, Universidad de Chile, Santiago

Courchesne F, Gobran GR (1997) Mineralogical variations of bulk and rhizosphere soils from a Norway spruce stand. Soil Sci Soc Am J 61: $1245-1249$

de Vries W, Reinds GJ, Gundersen P, Sterba H (2006) The impact of nitrogen deposition on carbon sequestration in European forests and forest soils. Glob Chang Biol 12:1151-1173. https://doi.org/ 10.1111/j.1365-2486.2006.01151.x

Diehl P, Mazzarino MJ, Funes F, Fontenla S, Gobbi M, Ferrari J (2003) Nutrient conservation strategies in native Andean-Patagonian forests. J Veg Sci 14:63-70. https://doi.org/10.1111/j.1654-1103. 2003.tb02128.x

Donoso C, Donoso P (2006) Nothofagus betuloides (Mirb) Oerst. In: Donoso Zegers C (ed) Las especies arbóreas de los bosques templados de Chile y Argentina: Autoecología. Marisa Cuneo Ediciones, Valdivia, pp 411-422
Dreiss LM, Volin J (2013) Influence of leaf phenology and site nitrogen on invasive species establishment in temperate deciduous forest understories. For Ecol Manag 296:1-8. https://doi.org/10.1016/j. foreco.2013.01.031

Frangi JL, Richter LL (1994) Balances hídricos de bosques de Nothofagus de Tierra del Fuego. Rev Fac Agron La Plata 70:65-79

Frangi JL, Barrera MD, Puig De Fábregas J, Yapura PF, Arambarri AM, Richter L (2005) Ecología de los bosques de Tierra del Fuego. In: Goya JF, Frangi JL, Arturi MF (eds) Investigación en bosques nativos de Argentina. Universidad Nacional de La Plata, Buenos Aires

Frederiksen P (1988) Soils of Tierra del Fuego. A Satellite-based Land Survey Approach. Folia Geographica Danica. Reitzels, Copenhagen $18: 159$

Gerding V, Thiers O (2002) Caracterización de suelos bajo bosques de Nothofagus betuloides (Mirb) Blume, en Tierra del Fuego, Chile. Rev Chil Hist Nat 75:819-833. https://doi.org/10.4067/S0716078X2002000400015

Hättenschwiler S, Tiunov AV, Scheu S (2005) Biodiversity and litter decomposition in terrestrial ecosystems. Annu Rev Ecol Evol Syst 36:191-218. https://doi.org/10.1146/annurev.ecolsys.36.112904. 151932

Hou E, Tan X, Heenan M, Wen D (2018) A global dataset of plant available and unavailable phosphorus in natural soils derived by Hedley method. Sci Data 5:180166. https://doi.org/10.1038/sdata. 2018.166

Ibarra M, Cruz G, Caldentey J, Cabello G (2007) Tipo Forestal coihue de Magallanes en la XII Región. In: Cruz G, Caldentey J (eds) Caracterización, Silvicultura y uso de los bosques de Coihue de Magallanes (Nothofagus betuloides) en la XII Región de Chile. CONICYT FONDEF, Santiago de Chile

IUSS Working group WRB (2015) World Reference Base for soil resources 2014, update 2015. International soil classification system for naming soils and creating legends for soil maps. World soil resources reports no. 106. FAO, Rome

Jacob M, Weland N, Platner C, Schaefer M, Leuschner C, Thomas FM (2009) Nutrient release from decomposing leaf litter of temperate deciduous forest trees along a gradient of increasing tree species diversity. Soil Biol Biochem 41:2122-2130. https://doi.org/10. 1016/j.soilbio.2009.07.024

Jandl R, Lindner M, Vesterdal L, Bauwens B, Baritz R, Hagedorn F, Johnson DW, Minkkinen K, Byrne KA (2007) How strongly can forest management influence soil carbon sequestration? Geoderma 137:253-268. https://doi.org/10.1016/j.geoderma.2006.09.003

Klein D, Fuentes JP, Schmidt A, Schmidt H, Schulte A (2008) Soil organic $\mathrm{C}$ as affected by silvicultural and exploitative interventions in Nothofagus pumilio forests of the Chilean Patagonia. For Ecol Manag 255:3549-3555. https://doi.org/10.1016/j.foreco.2008.03. 002

Kreps G, Martínez Pastur G, Peri P (2012) Cambio climático en Patagonia sur. Escenarios futuros en el manejo de los recursos naturales. Ediciones INTA, Buenos Aires

Li Y, Yang F, Ou Y, Zhang D, Liu J, Chu G, Zhang Y, Otieno D, Zhou G (2013) Changes in Forest soil properties in different successional stages in lower tropical China. PLoS One 8:e81359. https://doi. org/10.1371/journal.pone.0081359

Liu X, Meng W, Liang G, Li K, Xu W, Huang L, Yan J (2014) Available phosphorus in Forest soil increases with soil nitrogen but not Total phosphorus: evidence from subtropical forests and a pot experiment. PLoS One 9:e88070. https://doi.org/10.1371/journal.pone.0088070

Lucas-Borja ME, Candel Pérez D, López Serrano FR, Andrés M, Bastida F (2012) Altitude-related factors but not Pinus community exert a dominant role over chemical and microbiological properties of a Mediterranean humid soil. Eur J Soil Sci 63:541-549. https://doi. org/10.1111/j.1365-2389.2012.01438.x 
Mao Q, Lu X, Zhou K, Chen H, Zhu X, Mori T, Mo J (2017) Effects of long-term nitrogen and phosphorus additions on soil acidification in an N-rich tropical forest. Geoderma 285:57-63. https://doi.org/10. 1016/j.geoderma.2016.09.017

Martínez Pastur G, Cellini JM, Peri PL, Vukasovic RF, Fernández MC (2000) Timber production of Nothofagus pumilio forests by a shelterwood system in Tierra del Fuego (Argentina). For Ecol Manag 134:153-162. https://doi.org/10.1016/S0378-1127(99) 00253-4

Martínez Pastur G, Peri PL, Vukasovic R, Vaccaro S, Piriz Carrillo V (1997) Site index equation for Nothofagus pumilio Patagonian forest. Phyton 6:55-60

McCune B, Mefford MJ (1999) PC-ORD: multivariate analysis of ecological data; version 4 for windows [User's guide]. MjM software design

McCune B, Grace JB (2002) Analysis of ecological communities. MJM Software Design, Oregon

Mestre L, Toro-Manríquez M, Soler R, Huertas-Herrera A, Martínez Pastur G, Lencinas MV (2017) The influence of canopy-layer composition on understory plant diversity in southern temperate forests. For Ecosys 4:6. https://doi.org/10.1186/s40663-017-0093-z

Moore D (1983) Flora of Tierra del Fuego. Nelson/Missouri Botanical Garden, Oswestry, UK/St. Louis

Moretto AS, Martínez Pastur G (2014) Litterfall and leaf decomposition in Nothofagus pumilio forests along an altitudinal gradient in Tierra del Fuego. J For Sci 60:500-510. https://doi.org/10.17221/74/2014JFS

Osman KT (2013) Forest soils. Properties and Management. Springer, BAsel. https://doi.org/10.1007/978-3-319-02541-4_2

Parras-Alcántara L, Lozano-García B, Galán-Espejo A (2015) Soil organic carbon along an altitudinal gradient in the Despeñaperros Natural Park, southern Spain. Solid Earth 6:125-134. https://doi.org/10. 5194/se-6-125-2015

Peña-Rodríguez S, Moretto A, Pontevedra-Pombal X, Oro N, GarcíaRodeja Gayoso E, Rodríguez-Salgado I, Rodríguez-Racedo J, Escobar J, Nóvoa-Muñoz JC (2013) Trends in nutrient reservoirs stored in uppermost soil horizons of subantarctic forests differing in their structure. Agrofor Syst 87:1273-1128. https://doi.org/10. 1007/s10457-013-9635-8

Peri PL, Bahamonde H, Christiansen R (2015) Soil respiration in Patagonian semiarid grasslands under contrasting environmental and use conditions. J Arid Environ 119:1-8. https://doi.org/10. 1016/j.jaridenv.2015.03.008

Pisano E (1977) Fitogeografía de Fuego-Patagonia chilena. I.Comunidades vegetales entre las latitudes $52^{\circ}$ y $56^{\circ} \mathrm{S}$. Anales del Instituto de la Patagonia 8:121-250

Quesada CA, Lloyd J, Schwarz M, Baker TR, Phillips OL, Patiño S, Czimczik C, Hodnett MG, Herrera R et al (2009) Regional and large-scale patterns in Amazon forest structure and function are mediated by variations in soil physical and chemical properties. Biogeosci Discuss 6:3993-4057. https://doi.org/10.5194/bgd-63993-2009

Rao M, Nair P, Ong C (1997) Biophysical interactions in tropical agroforestry systems. Agrofor Syst 38:3-50. https://doi.org/10.1023/A: 1005971525590

Romanya J, Fons J, Sauras-Year T, Gutiérrez E, Vallejo VR (2005) Soilplant relationships and tree distribution in old growth Nothofagus betuloides and Nothofagus pumilio forests of Tierra del Fuego. Geoderma 124:169-180. https://doi.org/10.1016/j.geoderma.2004. 04.011

Rothe A, Binkley D (2001) Nutritional interactions in mixed species forests: a synthesis. Can J For Res 31:1855-1870. https://doi.org/ $10.1139 / \mathrm{x} 01-120$

Scheibe A, Steffens C, Seven J, Jacob A, Hertel D, Leuschner C, Gleixneret G (2015) Effects of tree identity dominate over tree diversity on the soil microbial community structure. Soil Biol Biochemi 81:219-227. https://doi.org/10.1016/j.soilbio.2014.11. 020

StClair SB, Lynch JP (2005) Element accumulation patterns of deciduous and evergreen tree seedlings on acid soils: implications for sensitivity to manganese toxicity. Tree Physiol 25:85-92. https://doi.org/10. 1093/treephys/25.1.85

Thiers O, Gerding V (2007) Variabilidad topográfica y edáfica en bosques de Nothofagus betuloides (Mirb) Blume, en el suroeste de Tierra del Fuego, Chile. Rev Chil Hist Nat 80:201-221. https://doi.org/10. 4067/S0716-078X2007000200006

Thiers O, Reyes J, Gerding V, Schlatter JE (2014) Suelos en ecosistemas forestales. In: Donoso C, González ME, Lara A (eds) Ecología forestal. Bases para el manejo sustentable y conservación de los bosques nativos de Chile. Ediciones UACh, Valdivia, Chile, pp 133-178

Toro Manríquez M, Mestre L, Lencinas MV, Promis Á, Martínez Pastur G, Soler R (2016) Flowering and seeding patterns in pure and mixed Nothofagus forests in southern Patagonia. Ecol Process 5:21-33. https://doi.org/10.1186/s13717-016-0065-1

Treseder KK, Vitousek PM (2001) Effects of soil nutrient availability on investment in acquisition of $\mathrm{N}$ and $\mathrm{P}$ in Hawaiian rain forests. Ecology 82:946-954. https://doi.org/10.1890/0012-9658

Utset A, Cid G (2001) Soil penetrometer resistance spatial variability in a Ferralsol at several soil moisture conditions. Soil Till Res 61:193202. https://doi.org/10.1016/S0167-1987(01)00204-5

Vankat JL (2002) Boreal and temperate forests. In: Vankat J (ed) The natural vegetation of North America. Wiley, Chichester

Vesterdal L, Schmidt IK, Callesen I, Nilsson LO, Gundersen P (2008) Carbon and nitrogen in forest floor and mineral soil under six common European tree species. For Ecol Manag 255:35-48. https://doi. org/10.1016/j.foreco.2007.08.015

Vitousek PM, Porder S, Houlton BZ, Chadwick OA (2010) Terrestrial phosphorus limitation: mechanisms, implications, and nitrogenphosphorus interactions. Ecol Appl 20:5-15

Wardle DA, Walker LR, Bardgett RD (2005) Ecosystem properties and forest decline in contrasting long-term chronosequences. Science 305:509-513. https://doi.org/10.1126/science.1109723

Wenk HR, Bulakh A (2004) Minerals. Their constitution and origin. Cambridge University Press, Cambridge

Zhang C, Tian HQ, Liu Y, Wang SQ, Liu ML, Pan S, Xueszheng S (2005) Pools and distributions of soil phosphorus in China. Global Biogeochem Cycles 19:1. https://doi.org/10.1029/2004GB002296

Publisher's note Springer Nature remains neutral with regard to jurisdictional claims in published maps and institutional affiliations. 